\title{
WACANA PKI DAN KEKERASAN SIMBOLIK DALAM PROGRAM MISTER(I) TUKUL "EPISODE PEMBANTAIAN KEDIRI"
}

\section{Oleh :Kamil Alfi Arifin}

Prodi Ilmu Komunikasi, Fakultas Ilmu Sosial dan Ekonomi

Universitas Respati Yogyakarta

www.alfi_madura@yahoo.co.id

\begin{abstract}
This article explores discourse of Indonesian's Communis Party (PKI) in reality show program of Mister(i) Tukul (Pembantaian Kediri's episode) and simbolic violence in its. This articles found that this program has reflected and repoduced discourse dominant of PKI. Thus, this program was regarded contain simbolic violence.
\end{abstract}

Keyword:

Reality show, discourse, PKI, and simbolic violence

\section{Pendahuluan}

Sejak awal tahun 2000-an, atau lebih tepat tahun 2004, program-program reality show berbau mistik menghiasi layar-layar televisi Indonesia. Programprogram tersebut menjamur dan menjadi semacam tren tersendiri di tanah air. Nyaris hampir semua stasiun televisi memiliki program reality show berbau mistik yang sama dan seragam, yang membedakan barangkali hanya sekedar di tingkat permukaan saja, seperti nama program, host, alur cerita, lokasi dan para pemain di dalamnya. Tapi, semuanya memiliki pola sama: menekankan unsur mistik.

Hal semacam ini, sebetulnya tidak terlalu mengherankan dalam dunia industri pertelevisian di Indonesia. Bukan rahasia umum lagi, jika ada satu program televisi yang menuai kesuksesan dengan ditandai perolehan rating yang tinggi, maka praktik peniruan atau epigonisasi oleh stasiun-stasiun televisi lain menjadi hal yang lumrah dilakukan. Meski sebenarnya, dalam penilaian yang idealistik, praktik-praktik seperti itu tak dianjurkan dilakukan karena dianggap tidak kreatif dan produktif. Untuk menyebut beberapa program reality show berbalut mistik itu di antaranya adalah Dunia Lain (Trans TV), Gentayangan 
(TPI), Pemburu Hantu (Lativi), Ih...Serem (TPI), Percaya Gak Percaya (ANTV), Cerita Masyarakat (Lativi) dan lain-lainnya ${ }^{1}$.

Meskipun pada tahun-tahun berikutnya, barangkali karena hasrat ingin keluar dari kejemuan, mencoba hal baru, atau karena banyaknya kritik yang menyoroti reality show berbalut mistik, kita melihat ada semacam upaya dari pelaku-pelaku industri pertelevisian untuk meninggalkan unsur mistik dan menekankan unsur-unsur lain dalam program-program reality show, seperti unsur komedi dan hal-hal yang unik.

Tapi sepertinya "percobaan" itu tidak bertahan lama, kita tetap melihat unsur mistik pada akhirnya tidak benar-benar ditinggalkan dan menjadi unsur penting dalam program-program reality show terakhir. Coba lihat, program Mister(i) Tukul, misalnya, yang paling kentara untuk dijadikan contoh.

Pada mulanya, program Mister(i) Tukul adalah Program Mister Tukul Jalan-Jalan (MTJJ) yang sama sekali tidak melibatkan dan menekankan unsur misteri di dalamnya. MTJJ merupakan program reality show yang mengangkat seputar kebudayaan dan keunikan-keunikannya di berbagai daerah nusantara serta menyelipkan unsur komedi. Seperti nama programnya, MTJJ dipandu oleh komedian terkenal Tukul Arwana, yang melakukan jalan-jalan ke berbagai daerah. Tapi di tengah jalan, tiba-tiba MTJJ berubah nama program menjadi “Mister(i) Tukul”. Jelas, dalam perubahannya, program ini menekankan unsur misteri yang sangat kental di dalamnya, meskipun tetap dengan konsep yang semula: melakukan jalan-jalan ke berbagai daerah nusantara, mengunjungi tempat-tempat bersejarah.

Dalam salah satu episode tayangannya, Mister(i) Tukul mengangkat topik yang penulis rasa cukup menarik. Yaitu, Tragedi Pembantaian Kediri. Episode ini menceritakan peristiwa bersejarah tentang pembantaian orang PKI, orang-orang yang dituduh PKI dan para simpatisannya di Kediri, Jawa Timur. Terlebih di Sungai Brantas dan Dusun Djengkol, yang memang merupakan salah satu dusun basis PKI di sana.

Hal ini menarik, karena bagaimanapun, PKI—akibat propaganda rezim Orde Baru melalui film, buku-buku sejarah, pembangunan monumen-

\footnotetext{
${ }^{1}$ Muzayin Nazaruddin dalam "Sinetron Religius: Sinetron Islami?", Jurnal Komunikasi UII, Volume 2, Nomor 2, April 2008.
} 
monumendan lain-lain-menjadi "mitos" di tanah $\operatorname{air}^{2}$. Ia menjadi teks yang mampu mengapungkan memori sosial kita hanya pada "kejahatan-kejahatan" dan "kebiadaban-kebiadabannya". Frasa "PKI" dan segala hal yang berbau "PKI" menjadi identik dengan suatu kejahatan yang mengerikan, menakutkan, dan harus dijauhi serta dimusnahkan dari bumi nusantara. Dengan stereotip dominan seperti itu, bagaimana program reality show berbalut mistik sebagai bagian dari budaya populer, apalagi memang menekankan hal-hal yang menyeramkan memposisikan PKI dan orang-orang PKI.

Tulisan ini akan fokus pada dua hal, yaitu bagaimana wacana PKI dalam program reality show "Mister(i) Tukul" terutama dalam episode Pembantaian Kediri ditampilkan dan kemungkinan adanya kekerasan simbolik yang bersemayam di dalamnya ${ }^{3}$.

\section{Wacana dan Kekerasan Simbolik: Sebuah Perspektif}

Dalam tulisan ini, penulis akan menggunakan konsep wacana (discourse) yang dirumuskan oleh Michel Foucault dan konsep kekerasan simbolik yang dirumuskan oleh Pierre Bourdieu sebagai landasan teoritik.

Wacana atau discourse dalam pemikiran Foucault adalah sekelompok pernyataan yang membicarakan topik tertentu, dalam kurun waktu tertentu. Bahkan lebih jauh dari itu, wacana bagi Foucault tidak terbatas hanya pada pernyataan tekstual, melainkan bisa sebuah gugus gagasan berupa institusi-

\footnotetext{
${ }^{2}$ Propaganda rezim Orde Baru dalam menampilkan PKI dilakukan melalui film, buku-buku sejarah, monumen-monumen dan yang lainnya. Saat ini, terlebih pasca Reformasi 98, muncul ke permukaan publik literatur-literatur alternatif/tandingan yang berisi analisa-analisa kritis dalam melihat peristiwa 65 , yang penekannya sama sekali berbeda dengan pandangan sejarah versi pemerintah Orba. Di antaranya, yang bisa disebut misalnya, "A Preliminary Analysis 1, 1965 Coup in Indonesia" yang ditulis oleh Ben Anderson dan Ruth McVey, keduanya dari Cornell University dan sangat terkenal di kalangan intelektual dan aktivis kiri di Indonesia. Artikel tersebut merupakan pandangan alternatif tentang 65 yang muncul lebih awal. Dalam waktu belakangan, juga ada buku "Dalih Pembunuhan Massal" yang ditulis oleh John Roosa. Buku ini menjadi buku yang masuk daftar terlarang oleh MA di masa Reformasi karena dianggap berbahaya. Dari penulis Indonesia, yang bisa disebut, James Luhulima, misalnya, yang menulis buku "Menyingkap Dua Hari Tergelap di Tahun 1965: Melihat Peristiwa G30SPKI dari Perspektif yang Lain". Namun, sekalipun sudah ditemukan upaya tandingan dan counter dalam melihat peristiwa 65 dan PKI, tapi tetap saja sebagian besar masyarakat Indonesia, diakui tidak, masih mengikuti streotipe dominan versi Orba tentang PKI. Hal ini karena barangkali saking hegemoniknya Orde Baru. Propaganda yang dilakukan sudah sedemikian merasuknya ke dalam alam bawah sadar masyarakat Indonesia.

${ }^{3}$ Saat artikel ini ditulis, program "Misteri(i) Tukul" sudah berhenti tayang. Tapi, episode-episode programnya, termasuk episode Pembantaian Kediri, dapat dilihat kembali di channel Youtube.
} 
institusi sosial.Wacana dalam kerangka pemikiran Foucault diyakini dapat mempengaruhi cara berpikir dan bertindak tertentu. Foucault (dalam Jorgensen dan Philip) mendefinisikan wacana sebagai berikut ${ }^{4}$ :

"Kita akan menyebut wacana sebagai sekelompok pernyataan yang sejauh ini merupakan milik formasi kewacanaan yang sama [...Wacana] terdiri dari sejumlah kecil pernyataan tempat bisa ditetapkannya sekelompok kondisi eksistensi. Dalam pengertian ini wacana bukanlah bentuk tanpa waktu yang ideal [...], dari awal sampai akhir, wacana bersifat historis - penggalan sejarah [...] yang memiliki batas, pembagian, transformasi, mode khusus temporalitasnya sendiri”.

Menurut Foucault, wacana merupakan alat dan efek dari kuasa. Dalam teori relasi kuasa pengetahuannya, Foucault memahami kekuasaan itu bukan sesuatu yang terpusat seperti dalam tradisi Marxis, melainkan sesuatu yang menyebar luas dan ada dimana-mana. Oleh sebab itu, wacana juga dapat dimaknai sebagai bentuk perluasan kuasa sebagai rezim pengetahuan karena telah menciptakan jenis pengetahuan dan gagasan tertentu. Dengan kata lain, suatu kuasa memproduksi pengetahuan melalui bahasa. Tujuannya jelas, dalam rangka untuk memosisikan subjek di dalam wacana. Pemosisian subjek inilah yang kemudian menjadikan "penindasan” dalam sebuah wacana dianggap seperti wajar, lumrah, benar dan apa adanya.

Di balik wacana-wacana yang berbeda di setiap periode sejarah, ada sebuah himpunan kaidah-kaidah yang menentukan bagaimana wacana-wacana muncul dan diatur, yang disebut oleh Foucault sebagai episteme. Wacana-wacana tersebut kemudian bertemu dengan wacana-wacana lain dalam sebuah perjuangan diskursif. Disinilah kata Foucault, wacana-wacana tersebut memunculkan perspektif dominan, dan diakui secara tidak sadar kebenarannya. Tegasnya, wacana-wacana yang beragam dalam masyarakat selalu dibopong oleh suatu

${ }^{4}$ Marrianne W. Jorgensen dan Louise J Philips dalam "Discourse Analisys: Theory dan Method", terj, hal 24. 
kekuasaan sehingga ia ditentukan apakah ia menjadi dominan atau wacana yang terpinggirkan. $^{5}$

Sementara kekerasan simbolik dalam pemikiran Pierre Boudieu adalah pemaksaan sistem simbolisme dan makna terhadap kelompok atau kelas sedemikian rupa sehingga hal itu dialami sebagai sesuatu yang $\operatorname{sah}^{6}$. Sama seperti Foucault, Bourdieu juga menyoroti bahasa dan kekuasaan. Bourdieu juga melihat kekuasaan itu menyebar dan seringkali bersembunyi di dalam cara-cara melihat dan menggambarkan dunia yang diterima secara luas oleh masyarakat dan tidak dipertanyakan benar tidaknya, termasuk melalui bahasa dan wacana ${ }^{7}$. Hanya saja, bedanya, Bourdieu juga masih melihat kekuasaan ekonomi dan politik dalam praktik-praktik penyebaran kekuasaan secara halus itu. Bourdieu masih berbicara kekuasaan ekonomi, politik, budaya, simbolik dan yang lainnya.

Menurut Bourdieu, sistem dominasi sosial harus senantiasa mendapatkan pengakuan dan diterima secara legitim untuk terus mempertahankan dirinya di sepanjang waktu. Oleh sebab itu, kata Bourdiue, diperlukan kekuasaan simbolik. Kekuasaan simbolik adalah konsep yang perlu dipahami sebelum masuk ke pemahaman soal apa itu kekerasan simbolik.

Dalam pengertian Bourdieu kekuasaan simbolik adalah kekuatan yang dapat dikenali dari tujuannya untuk mendapatkan pengakuan. Artinya, sebuah kekuasaan (baik itu ekonomi, budaya, politik dan lain-lain) yang memiliki kemampuan untuk tidak dikenali bentuk aslinya, kesewenang-wenangannya, dan kekerasannya. Kekuasaan simbolik tidak menekankan pada kepatuhan fisik apalagi dengan cara-cara yang represif. Melainkan menekankan pada kepatuhan kesadaran, yang dilakukan dengan cara-cara yang halus, bahkan sangat halus dan samar-samar, sehingga membuat orang atau kelompok yang terdominasi tidak merasa kalau dirinya sedang di dalam kendali lingkaran dominasi. Nah, perasaan tidak terdominasi, padahal sejatinya terdominasi inilah yang disebut kekerasan

\footnotetext{
${ }^{5}$ Eriyanto, Analisis Framing: Pengantar Analisis Teks Media, Yogyakarta, LKiS, 2008, hal 76.

${ }^{6}$ Pemahaman tentang teori kekerasan simbolis secara sistematis terdapat dalam bukunya berjudul "Reproduction in Education, Society and Culture", pada bagian chapter pertama. Lihat juga Richard Jenkins dalam "Pierre Bourdieu”, terj, hal, 157.

${ }^{7}$ Randal Jhonson dalam kata pengantar buku kumpulan tulisan Pierre Bordieu "Arena Produksi Kultural, Sebuah Kajian Sosiologi Budaya”, Kreasi Wacana.
} 
$\operatorname{simbolik}^{8}$. Orang atau kelompok yang terdominasi merasa sesuatu yang dilihatnya, sebagai benar adanya, sudah sedemikian seharusnya, memang demikian semestinya.

Wacana yang dianggap sudah sedemikian mestinya, tanpa dicek lagi kebenarannya, dalam bahasa Bourdiue disebut doxa. Dunia sosial dan kehidupan sehari-hari sebagai arena pertarungan, wacana-wacana yang dominan terus mempertahankan dirinya melalui mekanisme kekuasaan simbolik. Maka, setiap ada keberhasilan dari praktik-praktik kekuasan simbolik, selalu ada kekerasan simbolik di dalamnya.

\section{Narasi tentang PKI dalam Program Mister(i) Tukul}

Tidak semua scene dan narasi dari Program Mister(i) Tukul (Episode Pembantaian Kediri) ditampilkan dan dianalisis dalam tulisan ini. Scene dan narasi yang dipilih dan dianalisis hanya yang dianggap terkait dengan wacana PKI dan kekerasan simbolik yang ada di dalamnya. Dengan kata lain, scene dan narasi yang menegaskan secara eksplisit hal-hal yang berhubungan dengan PKI di dalam teks.

\section{Scene 1}

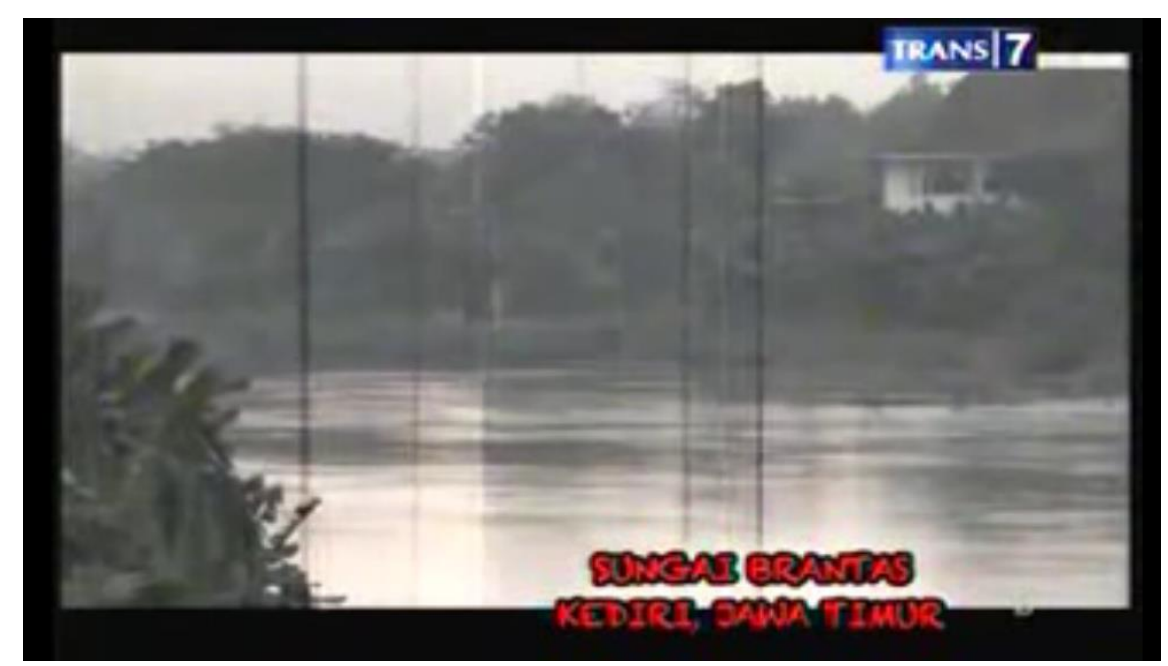

\footnotetext{
${ }^{8}$ Lihat, artikel ilmiah Suma Riella Rusdiarti "Bahasa, Pertarungan Simbolik dan Kekuasaan" dalam Majalah Basis, edisi November-Desember 2003.
} 


\section{Narasi}

Sungai Brantas merupakan salah satu sungai terpanjang di Pulau Jawa yang terkenal dengan cerita mistik dan misterinya. Konon katanya, Sungai Brantas ini dihuni oleh sesosok buaya putih yang selalu meminta tumbal. Tak hanya itu, Sungai Brantas juga merupakan lokasi pembantaian PKI pada tahun 65. Menurut warga, ketika itu hampir tiap hari mereka melihat puluhan jasad PKI dengan anggota tubuh yang tidak utuh sepanjang Sungai Brantas ini, namun tidak berani mendekat karena takut dituduh simpatisan PKI. Konon katanya, di Sungai Brantas ini sering terdengar suara tangisan, suara minta tolong dan penampakan orang berjalan tanpa kepala.

\section{Scene 2}

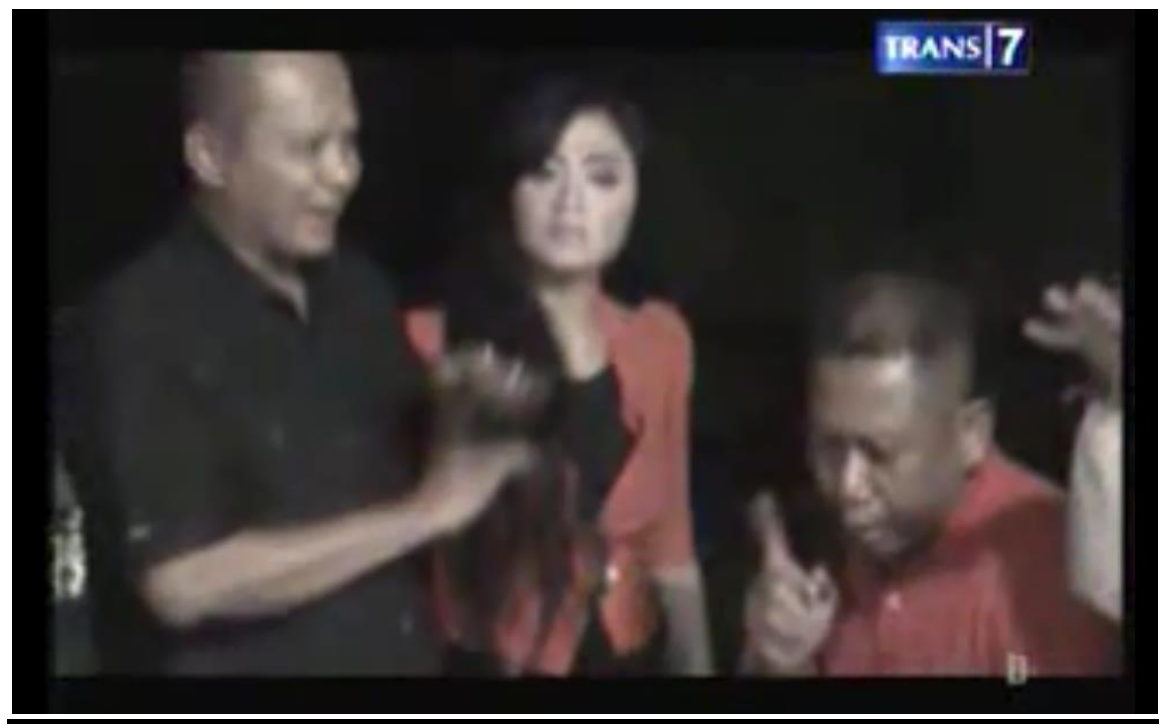

\section{Narasi:}

Mr Tukul Arwana (host): Tapi kan ada ngomongin soal PKI ini, Pak Sigit. Nah, eee...dimana lokasi pembantaian...apa... di sepanjang Sungai Brantas ini atau dimana?

Drs. Sigit Widiatmoko Mpd (Sejarawan, Narasumber): Pada tahun-tahun itu menunjukkan, cerita-cerita masyarakat banyak sekali.

Risa Saraswati (Paranormal, pendamping Host): Mayat-Mayat ya. 
Tukul: Mampir disini, bersandar di sini (sambil menunjuk Sungai Brantas). Kalau boleh tahu berapa sih jumlah mayat yang pernah ditemukan?

Pak Sigit: eem...kalau jumlah pastinya, kami memang tidak bisa memastikan, tapi ratusan.

\section{Scene 3}

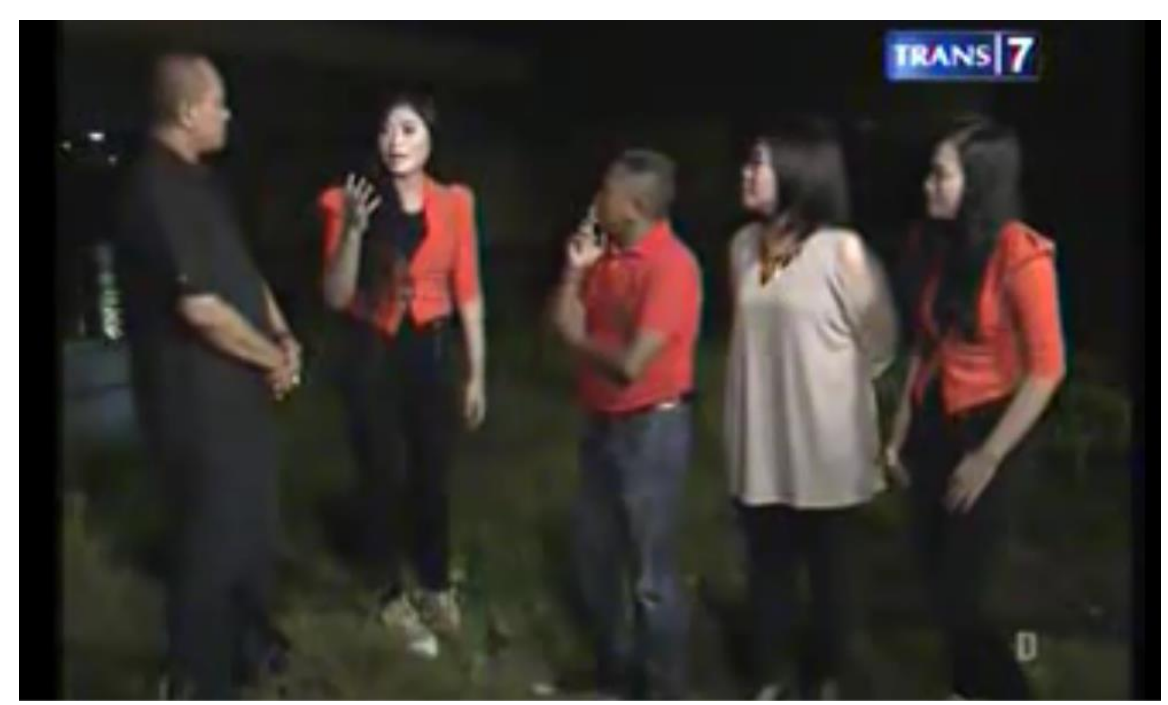

\section{Narasi:}

Dewi (Pendamping dan Tamu): Dengar-dengar ini ada berita, dulu waktu zaman PKI, itu banyak orang dibawa ke pinggir sungai, dibunuh, dibantai, mayatnya dibuang begitu saja. Sebenarnya seperti apa?

Pak Sigit: Iya memang betul, karena memang untuk menghilangkan jejaknya dan begitu mudah mereka membuang itu seperti kasus di Solo, jembatan, jembatan di pinggir sungai itu, dibuang. Bahkan, masyarakat di sini bercerita ada tiga orang yang dijadikan satu tanpa kepalanya, hanya badan. 


\section{Scene 4}

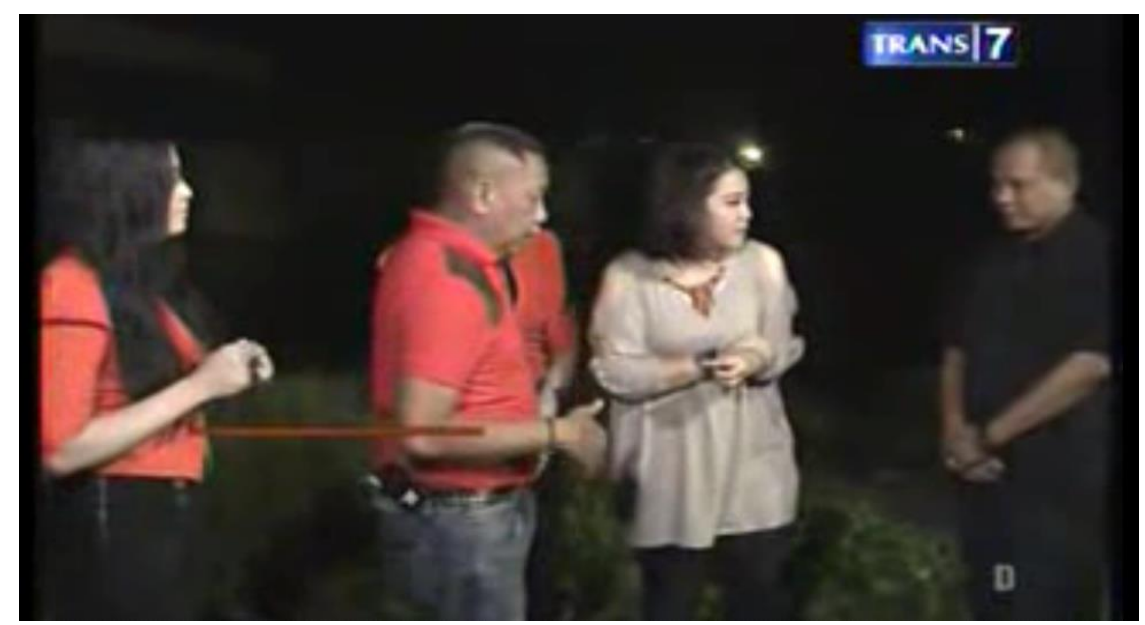

Tukul dan timnya bertanya pada Pak Sigit soal hubungan Sungai Brantas dengan Dusun Djengkol.

\section{Narasi:}

Pak Sigit: Oke, kalau kita memang, seperti yang saya ceritakan tadi, Brantas ini memiliki nilai mistis yang luar biasa, karena ini sungai yang memberi manfaat pada kehidupan masyarakat di sini. Kalau hubungannya dengan Djengkol seperti saya katakan tadi, kalau pembantaian-pembantaian PKI memang di daerah kediri itu memang tidak sebegitu luar biasa, kalau yang luar biasa dan fantastis di daerah Kediri itu memang di dusun Djengkol.

\section{Scene 5}

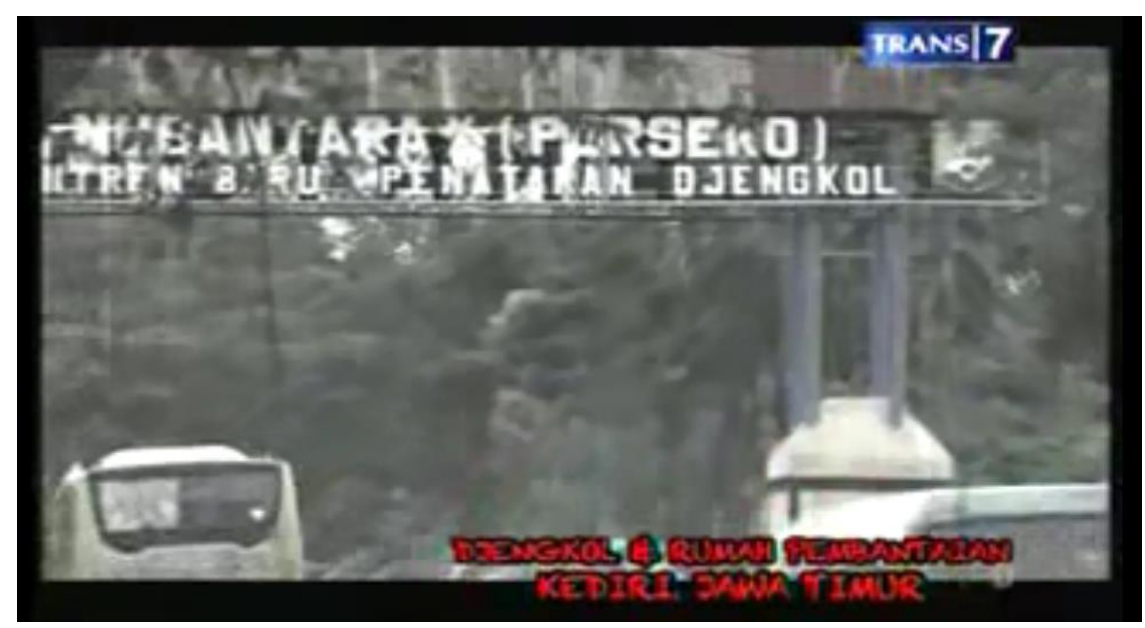




\section{Narasi:}

Djengkol merupakan sebuah dusun yang terletak di Kabupaten Kediri. Menurut warga, dulu dusun Djengkol merupakan markas terbesar PKI. Karena itulah, Djengkol merupakan lokasi pembantaian massal terbesar di Kediri. Tak hanya PKI, simpatisan, tetangga ataupun orang-orang yang hanya dicurigai PKI pun tak luput dari korban pembantaian. Pemandangan ini terjadi hampir di seluruh wilayah Djengkol, termasuk di rumah Belanda ini. Rumah ini dijadikan tempat tahanan PKI yang juga sekaligus menjadi tempat penyiksaan dan eksekusi. Konon kabarnya, ratusan orang dibunuh di rumah ini.

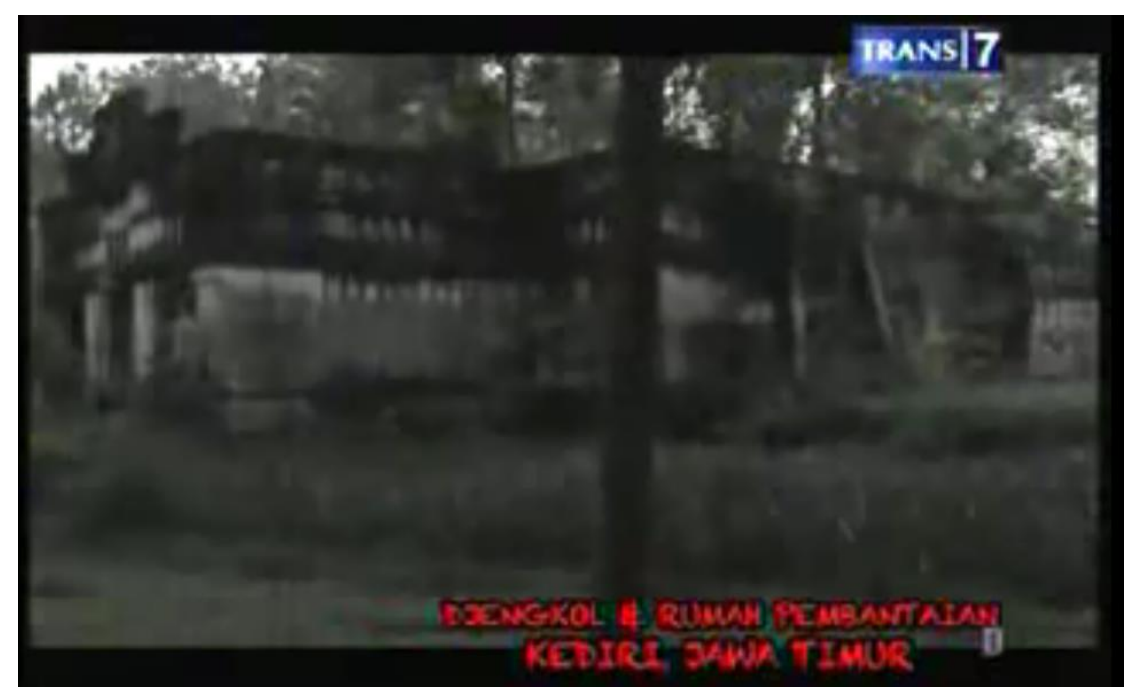

Scene 6

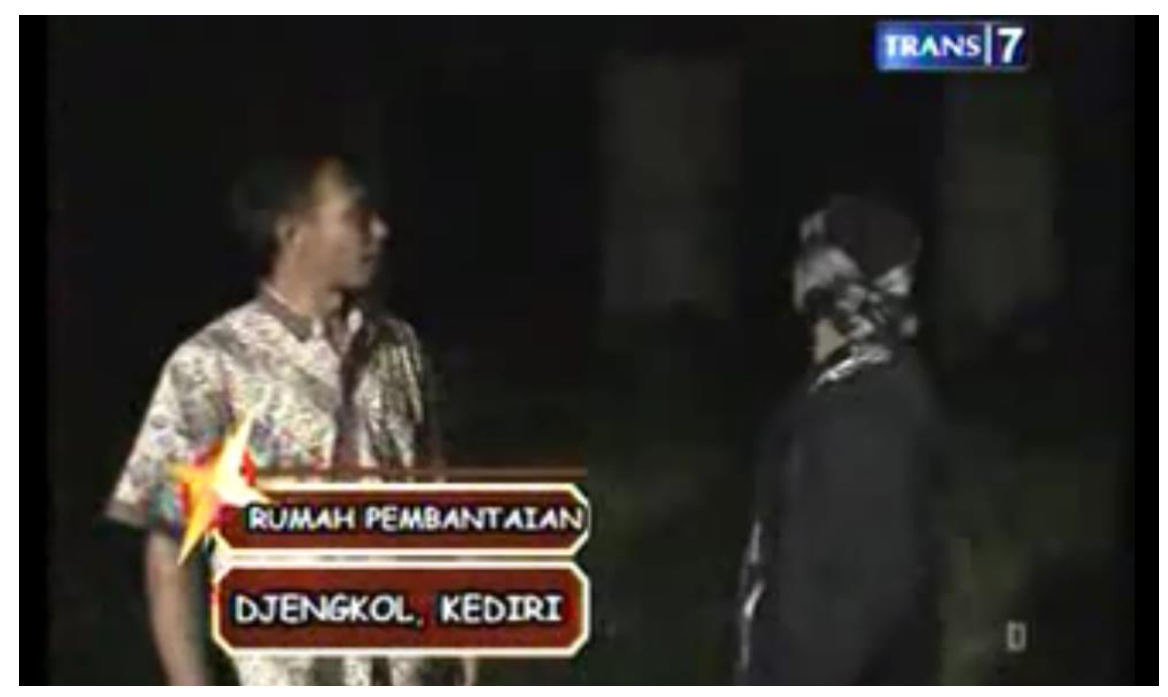




\section{Narasi:}

Ustad Sholeh Pati (Paranormal): Oh, ini bangunannya tua banget ya pak, Masya Allah (sambil melihat tahun yang tertera di depan bagian atas rumah).

Pujiono (warga Djengkol): Tahun ini, tahun buatan yang baru pak. Sebetulnya tahunnya bukan yang ini. Jadi sebelum tahun 1928 ini sudah ada. Setelah itu dikosongkan. Terakhir tahun 53, dikosongkan lagi, atap-atap sampe rusak. Setelah rusak, tahun 65 dibuat tahanan orang-orang G30S/PKI.

Ustad Sholeh: Seperti apa cerita tentang pembantaian itu pak?

Pujiono: Kalau cerita pembantaian, cerita orang yang tertua di Djengkol ini, orang yang ditahan ini, laki-laki ataupun perempuan itu ratusan. Jadi setelah ditahan di sini, diambil, dibantai di tempat sini, sebagian dibantai di tempat yang lain.

Ustad Sholeh: Itu banyak mana laki-laki dan perempuan?

Pujiono: ya banyak laki-laki.

Ustad Sholeh: Trus, saya dengar-dengar juga bukan hanya warga PKI saja yang dibantai tapi warga, istilahnya bukan, apa namanya, dari kaum PKI.

Pujiono: Ya dulu itu, saya kira ada orang yang make kesempatan, yang apa itu, cemburu, memfitnah.

Ustad Sholeh: Kenapa di sini, di dusun Djengkol ini banyak orang PKI pak?

Pujiono: Memang dulu itu di sini, wilayah Djengkol sampai ke timur itu wilayahnya PKI. Jadi di sini, daerah basis PKI tahun 65.

\section{Wacana PKI dan Kekerasan Simbolik dalam Program Mister(i) Tukul}

Dari beberapa scene dan narasi dalam program Mister(i) Tukul (Episode Pembantaian Kediri) yang ditampilkan di atas, dapat dilihat bagaimana wacana PKI diposisikan di dalam program Mister(i) Tukul. Program Mister(i) Tukul memposisikan PKI sebagai kelompok yang salah dan memang seharusnya dibantai, dihancurkan keberadaannya di Indonesia. Dikatakan demikian, karena di dalam teks, sama sekali tak dijumpai dan terlihat adanya semacam upaya untuk 
menjernihkan dan mengklarifikasi peristiwa pembantaian orang-orang PKI di Dusun Djengkol. Peristiwa pembantaian PKI di Dusun Djengkol diterima secara taken for granted untuk kepentingan memberikan dan menambahkan unsur misteri dalam tayangannya. Dengan kata lain, program Mister(i) Tukul membenarkan pembantaian PKI hanya untuk menambah kengerian dalam tayangannya. Karena memang program ini, sebagaimana dijelaskan sebelumnya, mengalami evolusi dari konsep yang semula hanya bercerita tentang keunikankeunikan kebudayaan tertentu di nusantara berganti konsep yang begitu memberikan penekanan pada unsur misteri dalam programnya.

Dengan begitu, Program Mister(i) Tukul masih merefleksikan pandangan dominan tentang PKI. PKI sebagai organ terlarang, PKI sebagai kelompok yang seharusnya dimusnahkan dan sebagainya, sebuah pandangan khas hasil propaganda canggih dan jahat Orde Baru yang masih diwarisi dan bertahan dari generasi ke generasi sampai saat ini. Padahal, perspektif baru tentang sejarah 65 sudah banyak bermunculan dan menuntut kita melihat kembali peristiwa tersebut dengan pandangan-pandangan yang lebih adil dan kritis ${ }^{9}$. Tapi program Mister(i) Tukul tidak melakukan itu. Barangkali karena tidak mau masuk pada kerumitan persoalan sejarah politik bangsanya, sehingga hanya berhenti pada sikap membenarkan adanya tragedi pembantaian, dan itupun dilakukan untuk kepentingan pragmatis sebagai bumbu misteri programnya. Tidak lebih. Coba lihat narasi ini "Dusun Djengkol merupakan markas terbesar PKI. Karena itulah, Djengkol merupakan lokasi pembantaian massal terbesar di Kediri. Tak hanya

\footnotetext{
${ }^{9}$ Pembantaian PKI Kediri, merupakan pembasmian berantai yang dimulai dari Jakarta, Jawa Tengah, Jawa Timur, lalu Bali, pasca meledaknya peristiwa Gerakan 30 September 1965. Pembasmian ini merupakan aksi yang didalangi oleh Suharto, militer, angkatan darat dan CIA. Kekuatan-kekuatan inilah yang kemudian memprovokasi rakyat untuk memusuhi dan membasmi PKI di tanah air. Di aras bawah, di daerah-daerah, termasuk di Kediri, ormas-ormas Islam seperti NU dan Muhammadiyah juga ormas-ormas lain diadu domba dengan PKI, sehingga pembasmian orang-orang PKI tidak hanya dilakukan oleh militer tetapi juga oleh para rakyat yang menjelma vigilante korban propaganda rezim Orba. Saat ini, setelah Reformasi, pandangan zaman telah berubah, ada semacam upaya untuk "membersihkan" nama PKI, baik upaya yang kritis dan rekonsiliatif. Tentang keterlibatan CIA dalam peristiwa 65 lihat "Dokumen CIA Melacak Penggulingan Sukarno dan Konspirasi G30S 1965” yang diterbitkan Hasta Mitra. Sementara upaya untuk membersihkan PKI, baik pandangan yang kritis dan pandangan yang rekonsiliatif, di antaranya bisa di lihat dalam surat terbuka Goenawan Mohammad dan Pramoedya Ananta Toer. Juga lihat novel-novel dan cerpen dengan tema 65 seperti karya Martin Aleida, Leila S Chudori "Pulang" dan "Amba" Laksmi Pamuntjak dan lain-lain. Bahkan Gusdur pun pernah meminta maaf kepada korban 65.
} 
PKI, simpatisan, tetangga ataupun orang-orang yang hanya dicurigai PKI pun tak luput dari korban pembantaian."

Narasi di atas, mencerminkan bagaimana program ini membenarkan pembantaian PKI. Kalimat "Dusun Djengkol merupakan markas terbesar PKI. Karena itulah, Djengkol merupakan lokasi pembantaian massal terbesar di Kediri" meneguhkan dengan sangat tegas dan terang jika PKI memang layak dan pantas dimusnahkan.

Selain itu, hal lain yang menunjukkan bagaimana PKI diposisikan sebagai organ yang terlarang dan kelompok yang harus dimusnahkan dari bumi Indonesia terlihat dari penekanan perbedaan antara orang-orang PKI dan orang-orang yang difitnah PKI. Lihat kembali pertanyaan ustad Sholeh Pati (salah seorang paranormal) yang bertanya kepada warga setempat yang dijadikan narasumber dalam program ini. "Saya dengar-dengar juga bukan hanya warga PKI saja yang dibantai tapi warga, istilahnya bukan, apa namanya, dari kaum PKI?”. Atau juga perhatikan narasi ini, "Sungai Brantas juga merupakan lokasi pembantaian PKI pada tahun 65. Menurut warga, ketika itu hampir tiap hari mereka melihat puluhan jasad PKI dengan anggota tubuh yang tidak utuh sepanjang Sungai Brantas ini, namun tidak berani mendekat karena takut dituduh simpatisan PKI."

Lihat dengan jelas antara "warga PKI" dan "bukan warga/kaum PKI" dalam pertanyaan dalam narasi di atas. Pemosisin biner antara warga PKI dan bukan warga PKI tersebut semakin meneguhkan bahwa PKI memang dianggap dan terima sebagai organ yang haram. Narasi itu seolah-olah membenarkan pembantaian terhadap orang-orang PKI, yang memang seharusnya dimusnahkan. Sementara pembantaian terhadap warga yang non PKI patut disesalkan. Jadi sangat jelas, Program Mister(i) Tukul dalam Episode Pembantaian Kediri mereproduksi pandangan sejarah, politik dan budaya dominan tentang PKI dan kesesatannya.

Sudah tentu, pereproduksian wacana dominan tentang kesesatan PKI dalam Program Mister(i) Tukul Episode Pembantaian Kediri merefleksikan sebuah kekuasaan simbolik. Program Mister(i) Tukul mengajak kita untuk meneguhkan jika PKI memang organ terlarang dan harus dimusnahkan dari Indonesia. Sebuah ajakan yang tidak memaksa, apalagi diselipkan dan 
ditempelkan dalam program populer, khas kerja kekuasaan simbolik yang memang tidak menekankan pada kepatuhan fisik apalagi dengan cara-cara yang represif. Melainkan menekankan pada kepatuhan kesadaran, yang dilakukan dengan cara-cara yang halus, bahkan sangat halus dan samar-samar, sehingga membuat orang atau kelompok yang terdominasi tidak merasa kalau dirinya sedang di dalam kendali lingkaran dominasi. Nah, pada titik ini, terdapat kekerasan simbolik dalam Progam Mister(i) Tukul Episode Pembantaian Kediri kekerasan simbolik yang mesti diwaspadai.

\section{Daftar Pustaka}

Bourdieu, Pierre. 2010. "Arena Produksi Kultural: Arena Produksi Kultural: Sebuah Kajian Sosiologi Budaya”. Kreasi Wacana: Yogyakarta.

Eriyanto. 2008. "Analisis Framing: Pengantar Analisis Teks Media". LKiS: Yogyakarta.

Isak, Joesoef (ed). 2002. "Dokumen CIA: Melacak Penggulingan Sukarno dan Konspirasi G30S 1965”. Hastra Mitra: Jakarta.

Jorgensen, Marianne W dan Phllips Louise J. 2007. "Analisa Wacana: Teori dan Metode”. Pustaka Pelajar: Yogyakarta.

Jenkins, Richard. 2004. "Membaca Pikiran Pierre Bourdieu". Kreasi Wacana: Yogyakarta.

Luhulima, James. 2006. "Menyingkap Dua Hari Tergelap di Tahun 1965: Melihat Peristiwa G30S dari Perspektif Lain”. Kompas: Jakarta.

Nazaruddin, Muzayin. "Sinetron Religius: Sinetron Islami?". Jurnal Komunikasi UII, Volume 2, Nomor 2, April 2008.

Roosa, John. 2008. "Dalih Pembunuhan Massal: Gerakan 30 September dan Kudeta Suharto”. Hastra Mitra: Jakarta.

Rusdiarti, Summa Riella. "Bahasa, Pertarungan Simbolik dan Kekuasaan”. Majalah Basis, edisi November-Desember 2003. 